\title{
Zakopane - od architektury fisowskiej lat 60. XX w. po czasy współczesne
}

\section{Zakopane - from the Fisian architecture of the 1960s to modern times}

\section{Streszczenie}

Po reformie administracyjnej kraju (1975 r.) Zakopane znalazło się w obrębie województwa nowosądeckiego. ArchitekPo reformie administracyjnej kraju (1975 r.) Zakopane znalazło się w obrębie województwa nowosądeckiego. Architektura z tego okresu prezentuje głównie późny modernizm i socmodernizm. W latach 80. opracowano trzecią koncepcję regulacji Zakopanego. Po raz pierwszy uwzględniono sprawy ochrony zabytków. $Z$ końcem lat 80 . i na początku 90 . wraz ze zmianami polityczno-ustrojowymi pojawiła się w Zakopanem architektura postmodernistyczna. W 1994 r. uchwalono miejscowy ogólny plan zagospodarowania przestrzennego. W 1998 r. uchwalono Studium uwarunkowań i kierunków zagospodarowania przestrzennego miasta Zakopanego. Architekturę zakopiańską XXI w. zdominowały obiekty wielkokubaturowe, hotele i tzw. apartamentowce.

Słowa kluczowe: Zakopane, socmodernizm, podhalańska architektura regionalna, późny modernizm, postmodernizm

\section{Abstract}

After the administrative reform of the country (1975), Zakopane found itself within the province of Nowy Sącz. Architecture from this period mainly presents late modernism and socmodernism. In the 1980s, the third concept of Zakopane regulation was developed. For the first time, it included monument protection. At the end of the 1980s and the beginning of the 1990s, postmodern architecture appeared in Zakopane along with political changes. In 1994, the local general spatial development plan for the city was adopted. In 1998, a study on the conditions and directions of the spatial development of the city of Zakopane was adopted. Twenty-first century Zakopane architecture was dominated by large buildings, hotels and apartment buildings.

Keywords: Zakopane, socmodernism, Podhale regional architecture, late modernism, postmodernism 


\section{ROZWÓJ ARCHITEKTURY W TATRACH I ZAKOPANEM. LATA SOCMODERNIZMU (1962-1980)}

\subsection{BUDOWNICTWO MIESZKANIOWE I USŁUGOWE ${ }^{1}$}

Gdy na przełomie lat 50. i 60. czas socrealizmu w Polsce dobiegał końca, wraz z nim o dziwo - skończyło się zapotrzebowanie na architekturę regionalną w obiektach wielkokubaturowych. Jednak pierwsze obiekty socmodernistyczne powstały w Zakopanem jeszcze w latach 50. Były to osiedla mieszkaniowe przy ul. Zamoyskiego (1952, proj. J. Dajewski) oraz przy Bulwarach Słowackiego (1958, proj. J. Dajewski).

W następnych latach w zakresie budownictwa mieszkaniowego wprowadzono na większą już skalę kolejne obiekty wielorodzinne (bloki), m.in. przy Drodze Do Tadziaków (19591962, proj. J. Nowakowski), przy ul. Słonecznej (1963-1964, proj. E. Warcaba), na Równi Krupowej (1965, proj. J. Dajewski), przy ul. Kościelnej (1965-1966, proj. E. Warcaba) i przy ul. Orkana (1966-1972, proj. E. Warcaba). Budownictwo usługowe dotyczyło potrzeb szkolnictwa, lecznictwa, handlu i żywienia zbiorowego oraz sportu i turystyki. Najbardziej charakterystycznymi obiektami tego typu, ale powszechnie krytykowanymi przez środowisko architektoniczne, były punktowce na Równi Krupowej (1960-1965, proj. J. Dajewski) oraz Spółdzielczy Dom Handlowy „Granit” (1960-1966, proj. A. Górska) (il. 27).

W latach 60. powstało na terenie Zakopanego kilkanaście zakładowych domów wczasowych budowanych przez różnych inwestorów. W pewnym stopniu mogło to zaspokoić zapotrzebowanie turystyki masowej na tanie miejsca noclegowe, bowiem wypady w Tatry mogły być organizowane z Zakopanego. Były to wyłącznie socmodernistyczne budynki, zupełnie pozbawione cech regionalnych, często projektowane przez twórców stylu nowozakopiańskiego. Z ważniejszych można wymienić domy wypoczynkowe: „Świerk” przy ul. Sienkiewicza (1962-1965, proj. A. Górska), „Kolejarz” przy ul. Kościuszki (1963-1965, proj. K. i J. Dobrowolscy), „Halny” przy ul. Kościuszki (1964, proj. A. Fołtyn), „Panorama” przy ul. Wierchowej (1965, proj. J. Dajewski), „Hyrny” przy ul. 15 Grudnia (obecnie ul. Piłsudskiego - 1966-1970, proj. Z. Miecznikowski, S. Miroszowski, T. Suwaj; proj. wnętrz I. Zaleśna).

Obok tego nurtu powstawały też nowoczesne budynki późnomodernistyczne: obserwatorium meteorologiczne na Równi Krupowej (1967, proj. J. Dajewski, J. Mechnicki), urząd miasta przy ul. Kościuszki (1969-1970, proj. B. Stefanik,), budynek TPN przy ul. Chałubińskiego (1977-1978, proj. W. Kłyszewski, J. Mokrzyński i E. Wierzbicki).

Stefan Żychoń zastanawiał się nad przyczynami zdominowania zabudowy Zakopanego na początku lat 60. XX w. przez formy nietradycyjne, zwłaszcza że „odwrót od architektury regionalnej nastąpił właśnie w tym czasie, gdy przyrost kubatury o nienotowanych w historii miasta rozmiarach miał zadecydować o jego obliczu"². 


\subsection{REGIONALIZM SOCMODERNISTYCZNY3}

W pierwszej połowie lat 70. XX w. wybudowano w Zakopanem kilka hoteli. W epoce Gierka co prawda nadal rozwijała się turystyka masowa, ale zaczęto dostrzegać także potrzeby turystyki indywidualnej. Dla ludzi o zasobniejszym portfelu, unikających zbiorowych sal w schroniskach turystycznych, obiekty te stawały się często dogodną alternatywą. Były to m.in. hotele: „Kasprowy” na Polanie Szymoszkowej (1973-1974, proj. i wyk. jugosłowiańska firma IMOS) (il. 30), „Juventur” przy ul. Słonecznej na Dolnej Równi Krupowej (1974, proj. J. Dajewski, J. Saba-Dobrzański), „Gazda” przy ul. Krupówki (1974, proj. E. Warcaba). Architektura tych budynków miała być kolejną propozycją nowocześnie rozumianego regionalizmu, który z perspektywy lat można nazwać „regionalizmem socmodernistycznym”, w swych założeniach znacznie odchodzącego od pierwotnych propozycji Witkiewicza.

Nadal rozwijało się budownictwo mieszkaniowe zdominowane przez tzw. wielką płytę. W tym czasie zrealizowano m.in. osiedla mieszkaniowe: na Kasprusiach (1974-1975, proj. J. Dajewski, Z. Remi, S. Tylka, urb. Z. Szpakowska) (il. 28), na Szymonach (1976-1977, proj. D. Kopkowicz, urb. A. Hrabala), przy ul. ks. Stolarczyka (1977-1979, proj. D. Kopkowicz), przy ul. Jagiellońskiej (1977-1978, proj. D. Kopkowicz), na Pardałówce (1979-1982), przy ul. Makuszyńskiego (1980-1982, proj. J. Dajewski), przy ul. Gimnazjalnej (1987-1992, proj. E. Warcaba). Doświadczenia tej architektury pobrzmiewają w obiektach wzniesionych w latach późniejszych, jak np. w domach wypoczynkowym Rady Ministrów - "Tatry” na Polanie Zgorzelisko oraz „Biały Potok” przy Drodze do Białego (1983, proj. Z. Trzupek, J. Urbanowicz).

Do nurtu architektury regionalnej zaliczyć można też kaplicę cmentarną na Olczy (1978-1980, proj. A. Nowotarski).

\section{PÓŹNY MODERNIZM I POSTMODERNIZM (1981-2019)}

\subsection{ARCHITEKTURA PÓŹNEGO MODERNIZMU}

Dopiero z końcem lat 80. i na początku 90., wraz ze zmianami polityczno-ustrojowymi, pojawiła się w Zakopanem na dobre architektura późnomodernistyczna, oczywiście dostosowana skalą do miejscowych potrzeb. Najbardziej reprezentatywna dla tego nurtu jest architektura sakralna. W 4. ćw. XX w. wzniesiono w Zakopanem kilka murowanych kościołów. W wielu tych budowlach samo użycie drewna - i to nie jako materiału konstrukcyjnego, lecz dekoracyjnego - traktowane jest jako nawiązanie do tradycji. Można do niej zaliczyć kościoły: pw. Najświętszej Maryi Panny Niepokalanej Objawiającej Cudowny Medalik na Olczy (1981-1987, proj. T. Gawłowski, T. Lisowska-Gawłowska) (il. 29), pw. Świętego Krzyża przy ul. Zamoyskiego (1983-1991, proj. W. Cęckiewicz), pw. Niepokalanego Serca NMP na 
Krzeptówkach (1987-1991, proj. S. Tylka), przy ul. Chramcówki (pw. Miłosierdzia Bożego; 1989-1994, proj. J. Ingarden), na Cyrhli (pw. Miłosierdzia Bożego; 1988-2000, proj. T. Jędrysko).

Architekturę sakralną w Zakopanem z tego czasu charakteryzuje nowatorska forma, nawiązująca w pewnym sensie do formy kościołów namiotowych. Najbardziej znany kościół na Olczy przypomina inną świątynię wzniesioną według projektu tego samego autora w Rudach Rysich (1965-1976), o której Andrzej K. Olszewski pisał, że była „wydarzeniem na skalę światową"5.

Z obiektów świeckich do ważniejszych należą: Bank PKO przy ul. Krupówki (1991-1993, proj. W. Buliński), Ośrodek Wypoczynkowy „Bankowiec” przy Bulwarach Słowackiego (1993-1995, proj. W. Buliński), restauracja McDonald's przy ul. Krupówki (1993-1995, proj. R. Rafacz, P. Kobylański, J. Liszkowski), dolna stacja kolejki na Gubałówkę (19961997, proj. Z. Remi, T. Gluziński), budynek handlowo-usługowy na rogu ul. Witkiewicza i Zamoyskiego (1995-1999, proj. K. Kiełba).

\subsection{ARCHITEKTURA POSTMODERNISTYCZNA ${ }^{6}$}

Postmodernizm to termin stosowany początkowo w krytyce literackiej. W odniesieniu do architektury został wykorzystany ponad trzydzieści lat temu. Chodziło o nazwanie nurtu powstającego na gruzach późnego modernizmu, a więc kierunku lansującego funkcjonalność w połączeniu z zaawansowaną technologią. Architektura postmodernistyczna podkreśla znaczenie kontekstu miejskiego i powrót do historycznych środków wyrazu takich jak ornament (m.in. dekoracja fasady i wnętrz motywami ornamentalnymi, rzeźbami czy polichromią). Ale w praktyce rozróżnienie architektury późnego modernizmu i postmodernizmu nie zawsze jest łatwe. Bowiem gdy postmodernizm podkreśla wagę lokalnej tradycji, późny modernizm nawołuje do regionalizmu (czy też „krytycznego regionalizmu”).

W Zakopanem architektura postmodernistyczna pojawiła na początku XXI w. i jej program został oczywiście znacznie zredukowany, przez co często graniczy z późnym modernizmem. Do obiektów tego nurtu można zaliczyć: wieżę sędziowską na Wielkiej Krokwi (2001-2002, proj. S. Karpiel z zespołem), zespół basenów i hotel Aqua Parku przy ul. Jagiellońskiej (2001-2005, proj. P. Łabowicz, T. Bajwoluk, M. Kulpa, P. Kuźma, J. Saj), hotel „Murowanica” przy alei Przewodników Tatrzańskich (2006-2008, proj. A. i R. Rafacz), apartamentowiec "Stara Polana” przy ul. Nowotarskiej (2007-2009, proj. S. Topór) (il. 36), apartamenty "Szklane Domy" na Ciągłówce 6a (2008-2009, proj. A. i R. Rafacz), Centrum Handlowe PSS „Szymonek” na Chycowym Potoku (2008-2009, proj. A. i R. Rafacz), budynek mieszkalny przy ul. Jagiellońskiej 33a (2010-2011, proj. J. Karpiel-Bułecka jun. i M. Steindel).

Nowoczesną architekturę reprezentują także obiekty zapowiadające schyłek późnego modernizmu pod Giewontem. Wyraźne cechy postmodernizmu pojawiły się po raz pierwszy w architekturze kamienicy Adama Bachledy-Curusia przy ul. Krupówki 29 (2006-2008, 
proj. A. i R. Rafacz) oraz budynku mieszkalno-usługowego wzniesionego w miejscu dawnej „Polonii” przy ul. Grunwaldzkiej (2011-2013, proj. S. Topór) (il. 37). Natomiast internat COS przy ul. B. Czecha (2012-2013, proj. S. Karpiel, T.T. Stopa, P. Walorek) (il. 38) nosi wyraźne cechy dekonstruktywizmu. Swoisty regionalny postmodernizm reprezentuje sklep Biedronka przy skrzyżowaniu ul. Piłsudskiego i Makuszyńskiego (2011-2012, proj. J. Karpiel-Bułecka jun. i M. Steindel), w którym zastosowano gontowy szalunek elewacji, pensjonat "Manru” przy ul. Grunwaldzkiej (2011-2012, proj. S. Topór), budynek usługowy z cukiernią „Samanta" dobudowaną do budynku przy ul. Krupówki 4 (2015-2016, proj. J. Burdziński) (il. 39) oraz przeskalowane Centrum Handlowe „Krupówki” w miejscu dawnego Cocktail-Baru, ul. Krupówki 40 (2012-2018, proj. A. i R. Rafaczowie) (il. 40).

Budynki wznoszone w ostatnich latach cechuje często zbyt duża kubatura ze względu na ich lokalizację obejmującą miejsce po dwóch, a nawet trzech obiektach, np. wspomniane Centrum Handlowe „Krupówki”.

\subsection{ARCHITEKTURA REGIONALNA PRZEŁOMU STULECI7}

Na szczęście twórcy i inwestorzy nie zapomnieli o obiektach drewnianych, tak ważnych w krajobrazie kulturowym Zakopanego i Podhala. Drewno stało się materiałem chętnie wykorzystywanym do budowy obiektów gastronomicznych oraz wypoczynkowych, choć powstają też drewniane wille. Do tego nurtu zaliczają się m.in.: „Skorusa” na Lipkach (1990, proj. Z. Remi), „Sieckowa Sopa” przy ul. Kościeliskiej (1995, proj. J. Karpiel-Bułecka sen., S. Michałczak), „Dworek Bawarski” przy ul. Bogdańskiego (1995, proj. Z. Gądek) (il. 32), „Nosalowy Dwór" przy Drodze Oswalda Balzera (2000, proj. W. Dudziak, T. Gluziński, A. Szkiłońdź), „Kmicic” przy ul. Grunwaldzkiej (2000, proj. A. Orłowski, M. Krawczyński), karczmy „Młyniska” (2000, proj. J. Karpiel-Bułecka sen.) (il. 31) i „Czarci Jar” na Małem Żywczańskiem (2001, proj. A. Krzanik), zespół szałasów i restauracja przy ul. Strążyskiej (2001-2002, proj. A. Bukowski-Tyrała, Z. Nawara), „Biały Potok” przy Drodze do Białego (2003-2004, proj. S. Topór). Wielu z wymienionych architektów jest też projektantami licznych drewnianych willi.

Elementami regionalnymi przyozdobione są także mniejsze obiekty sakralne, np. murowane, ale z dachami gontowymi, kaplice cmentarne w Zakopanem - na Harendzie (1997, proj. Z. Śliwiński) i Pardałówce (2001-2007, proj. Z. Remi). W nurcie architektury regionalnej pojawiły się też ryzykowne eksperymenty, które obecnie znajdują poklask wśród przyjeżdżających gości, ale nie podobają się mieszkańcom, nie mówiąc już o zakopiańskich architektach. Do takich budynków zaliczyć można np. willę „Kominiarski Wierch” przy ul. Kościeliskiej (2006-2008, proj. S. Pitoń) (il. 33).

Nurt architektury regionalnej, mniej lub bardziej udanej, reprezentują: apartamentowce przy Lipkach (2005, proj. A. Haber-Rudolf, M. Rudolf), osada mieszkalna „Za Strugiem” (2006-2007, proj. A. i R. Rafacz), pensjonat „Anuś” na Pardałówce (2006-2007, proj. P. Leja), hotel „Crocus” przy ul. Chałubińskiego 40 (2006-2008, proj. A. i R. Rafacz), apartamenty 
„Kaszelewskiego” przy ul. Kaszelewskiego 7c (2007-2008, proj. A. i R. Rafacz), apartamenty „Olczyska” przy ul. Wojdyły 13 (2007-2008, proj. A. i R. Rafacz), apartamenty "Oaza” przy ul. Grunwaldzkiej (2008-2009, proj. K. Kiełb), hotel „Grand Nosalowy Dwór” przy ul. O. Balzera 21d (2008-2009, proj. A. i R. Rafacz), hotel „Sobiczkowa” na Sobiczkowej-Bór (2008-2009, proj. A. i R. Rafacz), budynek mieszkalny przy ul. Jagiellońskiej 33 (2009, proj. S. Topór), budynek handlowy H\&M przy ul. Krupówki (2009-2010, proj. T. Trojan-Korn, P. Szlachtowski, S. Szatko), hotel „Rysy” przy ul. Goszczyńskiego (2009-2010), budynek handlowy przy ul. Sabały (2010, proj. A. Haber-Rudolf i M. Rudolf), budynek rekreacyjny przy willi „Witkiewiczówka” na Antałówce (2013, proj. K. Kiełb, współpraca J. Kowalczyk) (il. 35) oraz kamienica przy ul. Krupówki 25 (2013-2015, proj. Z. Śliwiński sen.) ${ }^{8}$.

\section{ZAKOŃCZENIE}

Zanim pod koniec XVI w. dotarło pod Giewont osadnictwo stałe, na halach tatrzańskich wypasali swe owce pasterze ze wsi Niżniego Podhala, a wraz z nimi pojawiły się tu szałasy i koliby pasterskie. Był to początek podhalańskiego budownictwa ludowego w tym rejonie. Pierwsze formy architektoniczne obce ludowej tradycji przyniesione zostały przez hawiarzy i hamerników, prawdopodobnie jeszcze w XVII w. Oba nurty przybrały zdecydowane formy stylistyczne w XVIII w. i od tej pory w Zakopanem obok budownictwa ludowego, a potem architektury regionalnej (podhalańskie budownictwo ludowe, styl zakopiański, styl zakopiański drugi, nowy regionalizm - wolny funkcjonalizm, styl nowozakopiański po współczesny regionalizm) rozwijał się nurt kosmopolityczny (klasycyzm, styl szwajcarski, historyzm i eklektyzm, modernizm i funkcjonalizm, socmodernizm po późny modernizm).

To bardzo wczesne rozdwojenie tendencji wpłynęło na dzisiejszy wygląd Zakopanego i stanowi wiecznie powracający dylemat zarówno dla planistów formułujących wytyczne architektoniczne do projektowania, jak i dla architektów będących autorami dokumentacji wznoszonych w naszym mieście budynków - architektura regionalna czy uniwersalna? Dotyczy to także problematyki ochrony zabytków w mieście. Być może należy różnorodność form architektonicznych pod Giewontem zacząć traktować jako wartość, a nie wadę.

W 1921 r. Leon Chwistek postulował - w ślad za włoskimi futurystami (reprezentantem był m.in. Virgilio Marchi) i niemiecką grupą Gläserne Kette (reprezentantem był m.in. Hermann Finsterlin) - zerwanie z wszelkimi ograniczeniami w dziełach architektury. Pisał on m.in.:

Otóż zadawanie sobie stale przymusu przebywania w nieznośnem otoczeniu jest niewątpliwie równoznaczne z osłabianiem systemu nerwowego. Przeciwnie, otoczenie pełne niespodzianek, zakamarków, schodków itp., jakiego dostarcza wiele starych budynków, działa podniecajqco i wypełnić może samym faktem swego istnienia niejednq beznadziejnie pustq chwilę. $Z$ tego powodu sqdzę, że budownictwo przyszłości nie może przeprowadzić konsekwentnie linii wytkniętej przez Perreta. Przeciwnie, 
nie rezygnujq̨c ze zdobyczy już uzyskanych przez nowożytne budownictwo, musi wyrwać starym gmachom tajemnicę rozmaitości i niespodzianki i przystosować ja do nowych rysunków ${ }^{9}$.

Zastanawiając się nad tym, jak to zrobić, stwierdził:

Ale dlaczego właściwie okna majq być pionowe? Dlaczego linie werand majq być proste? Czy zachowanie linii prostej $w$ dzisiejszych budynkach żelazo-betonowych nie jest przypadkiem automatycznie powtarzaniem kształtów, które podyktowane zostały swojego czasu prostq koniecznościq posługiwania się kamieniem lub cegła? Pytanie to wydaje się decydujqce. Pociaga ono za sobq cały szereg pytań szczegółowych, odnoszq̨cych się do kształtu pokoi, zwłaszcza salonów, buduarów itp., do urzq̨dzenia wewnętrznego itd. Wszystko to prowadzi po chwili zastanowienia do wniosku, że jeśli nie chcemy identyfikować wygody z tem, do czego przywykliśmy, a raczej żq̨ni jesteśmy odmiany, niespodzianki i rozmaitości, musimy zerwać zasadniczo z liniq prostą $w$ architekturze ${ }^{10}$.

Ciekawe, czy przeciętny odbiorca zaakceptowałby dzisiaj zaprojektowany przez Leona Chwistka hotel w Zakopanem, ale nie na rysunku, tylko po wzniesieniu, np. w okolicach Równi Krupowej czy na Gubałówce? Ale może nie cofajmy się do lat międzywojennych, tylko spójrzmy w przyszłość. Czy w Zakopanem sprawdzi się architektura performatywna ${ }^{11}$, której ostateczną formę nadają komputery? Czy byłaby to właściwa droga rozwoju architektury pod Giewontem? 


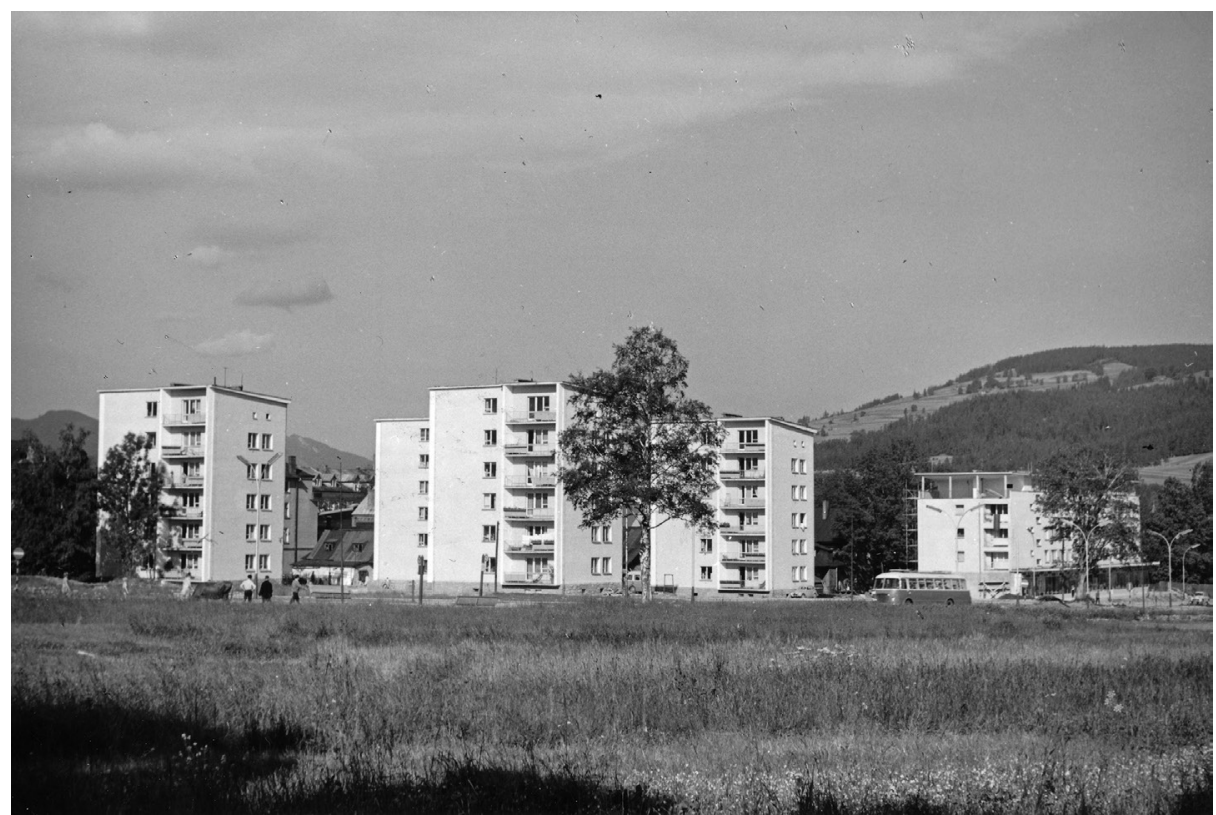

II. 28. Osiedle mieszkaniowe przy al. 1 Maja, obecnie al. 3 Maja (1963-1965, proj. J. Dajewski). Fot. Władysław Werner, 1965. MT-ZA, sygn. AF/07493/MT/III-015

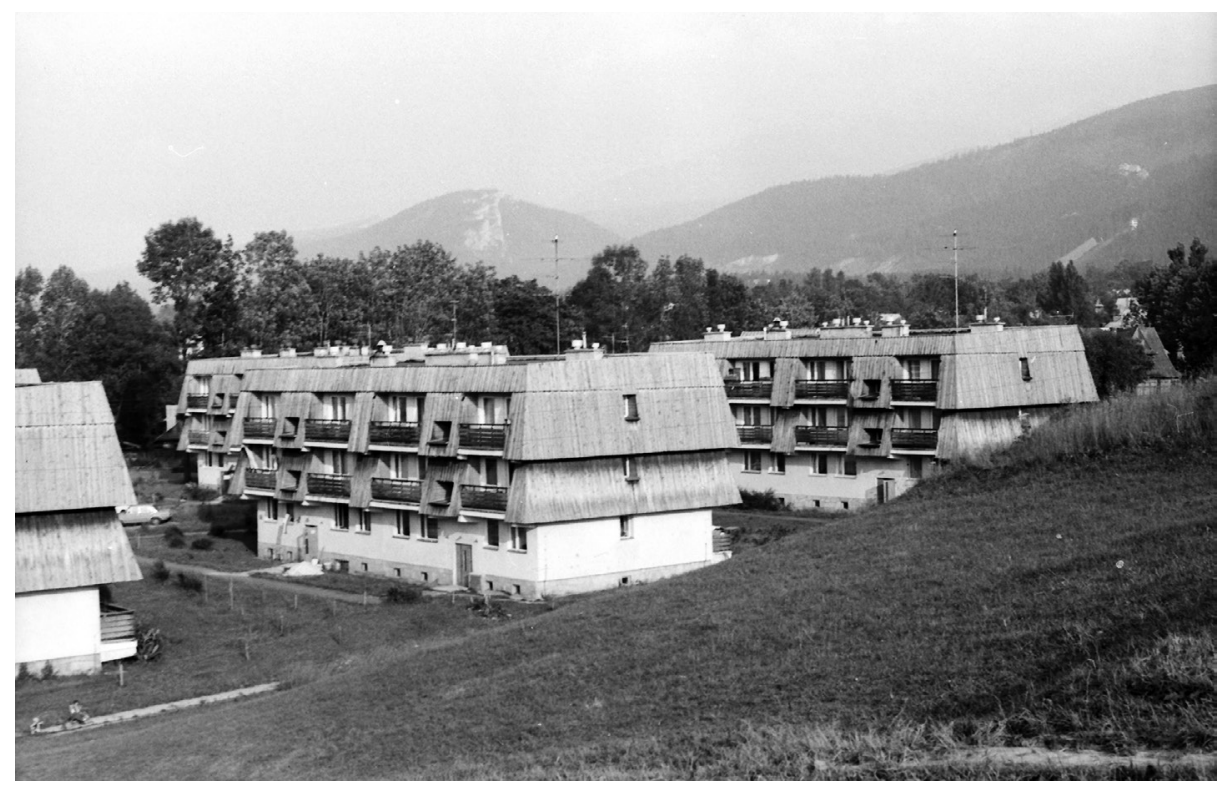

II. 29. Osiedle Lipki przy ul. Kasprusie (1974-1978, proj. arch. J. Dajewski, Z. Remi, S. Tylka, proj. urb. Z. Szpakowska). Fot. Zbigniew Moździerz, 1985. Zbiory prywatne 


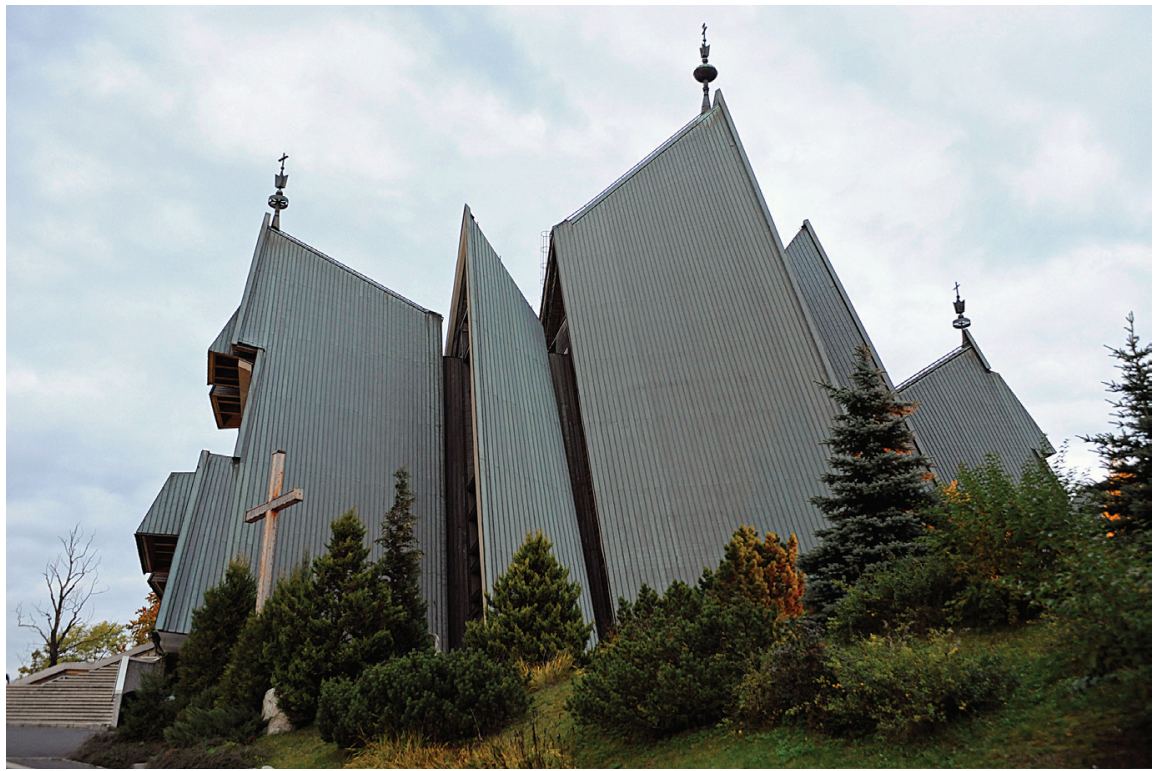

II. 30. Kościół pw. Matki Boskiej Objawiającej Cudowny Medalik na Olczy (1981-1988, proj. T. Gawłowski, T. Lisowska-Gawłowska). Fot. Dawid Moździerz, 2008. Zbiory prywatne

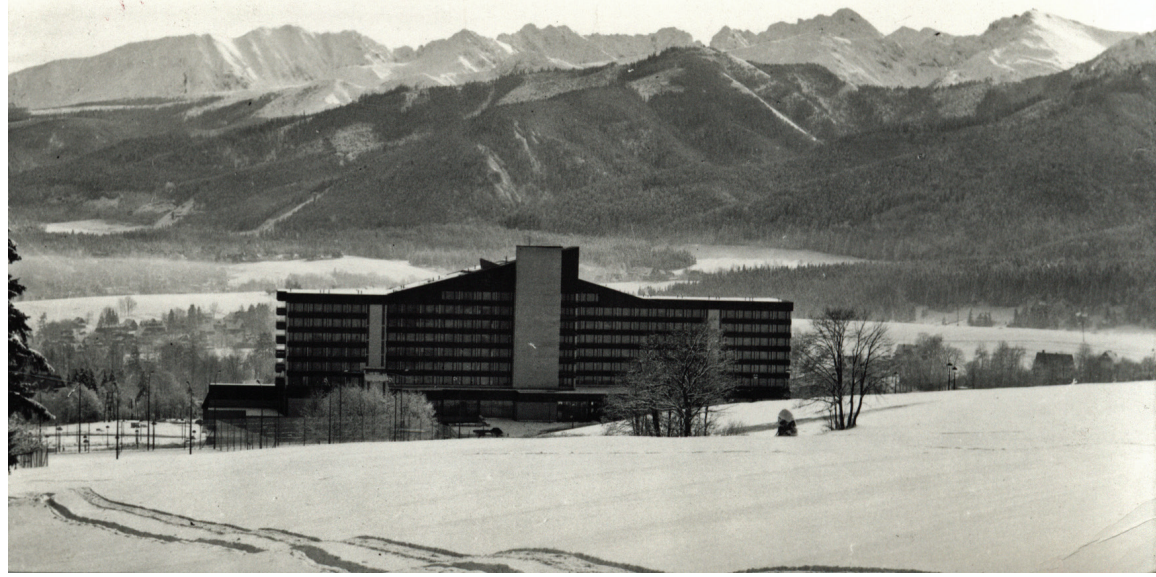

II. 31. Hotel „Kasprowy” na Polanie Szymoszkowej (1973-1974, proj. i wyk. jugosłowiańska firma IMOS). Fot. Roman Serafin, 1976. Pocztówka MT-ZA 


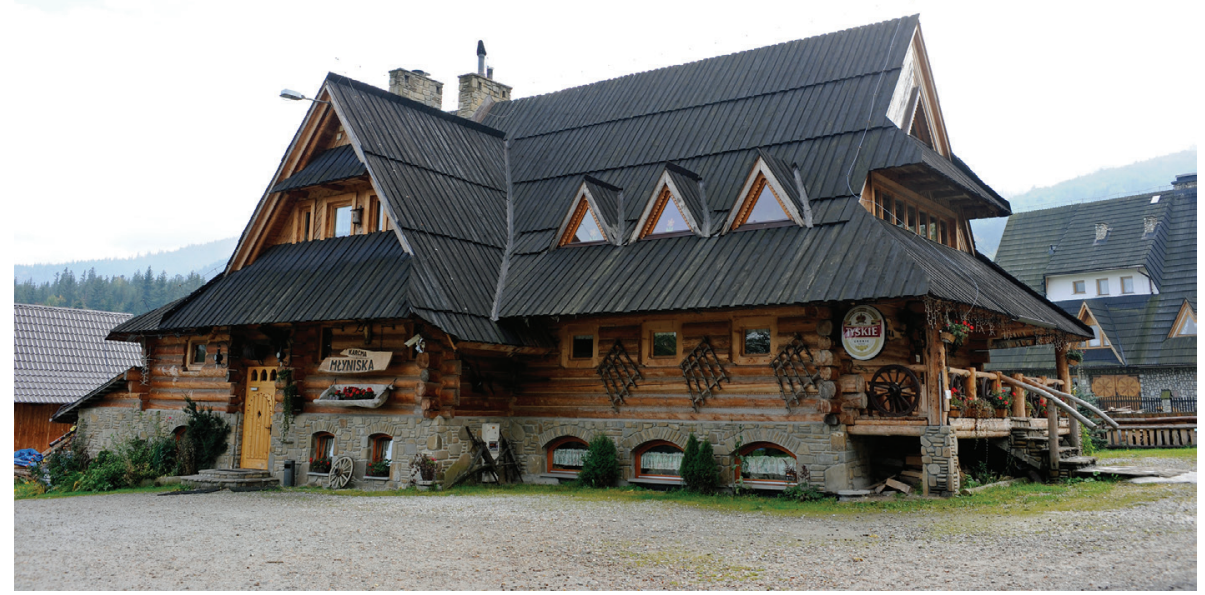

II. 32. Karczma „Młyniska” przy Drodze do Daniela (2000, proj. J. Karpiel „Bułecka” sen.). Fot. Dawid Moździerz, 2009. Zbiory prywatne

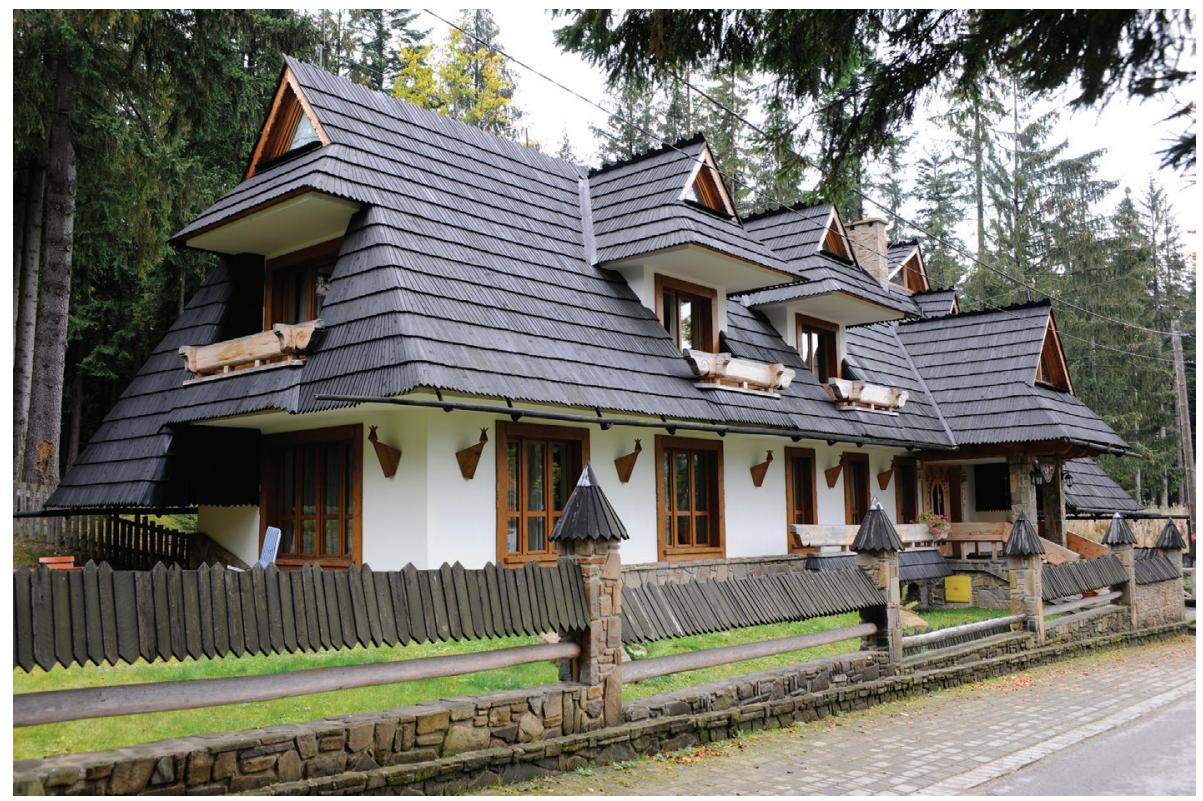

II. 33. Pensjonat „Dworek Bawarski” przy ul. Bogdańskiego (proj. K. Gądek).

Fot. Dawid Moździerz, 2009. Zbiory prywatne 


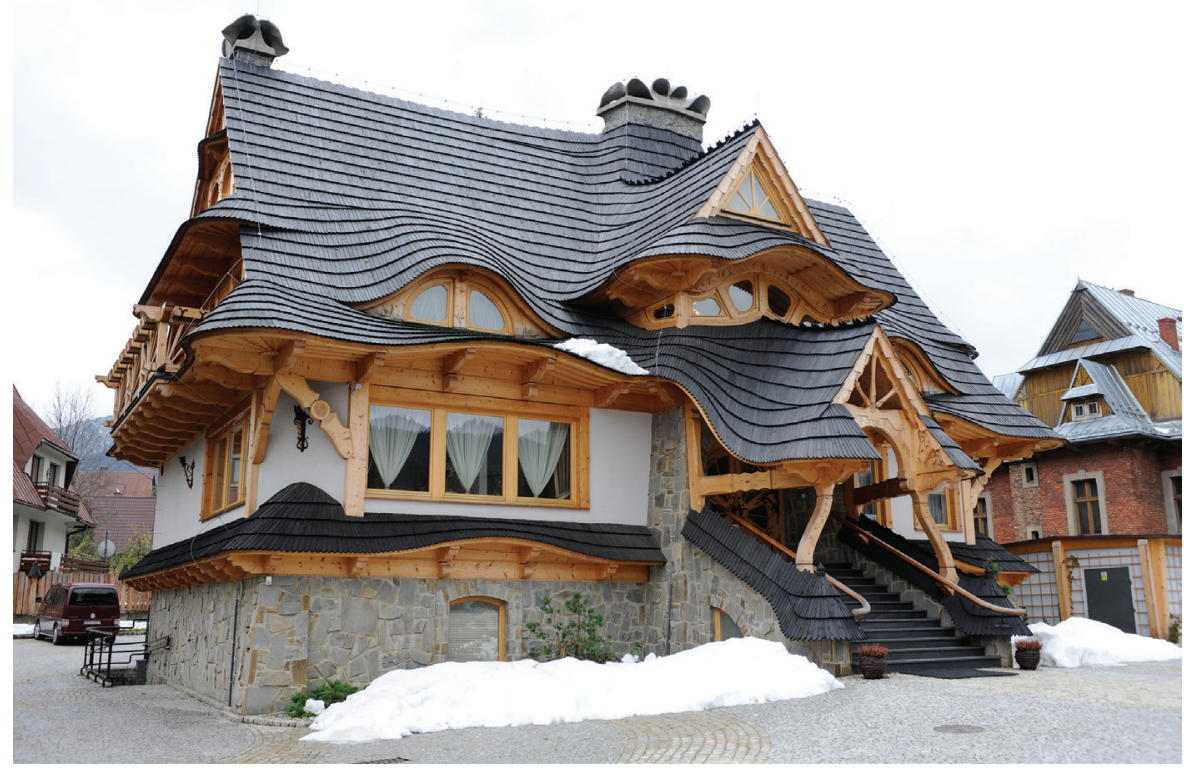

II. 34. Willa „Kominiarski Wierch” przy ul. Kościeliskiej (2008-2009, proj. S. Pitoń). Fot. Dawid Moździerz, 2009. Zbiory prywatne

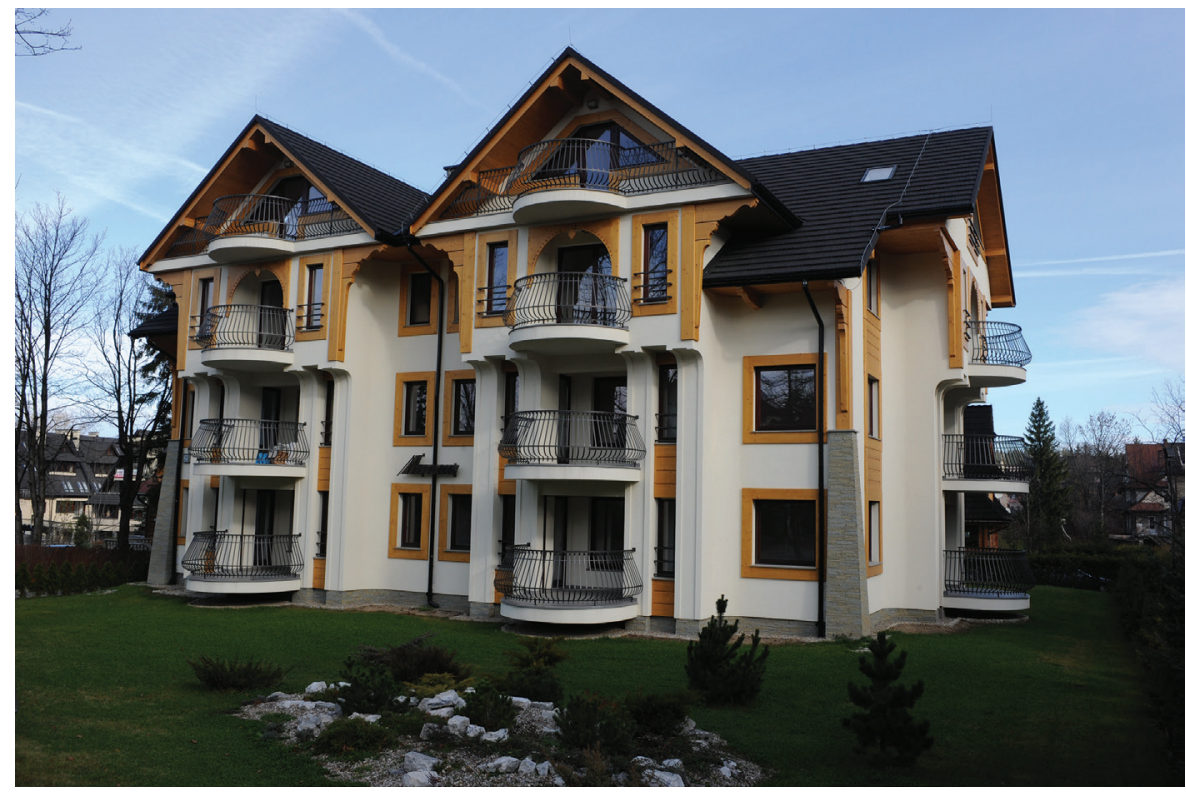

II. 35. Pensjonat „Manru” przy ul. Grunwaldzkiej (2011-2012, proj. S. Topór). Fot. Dawid Moździerz, 2012. Zbiory prywatne 


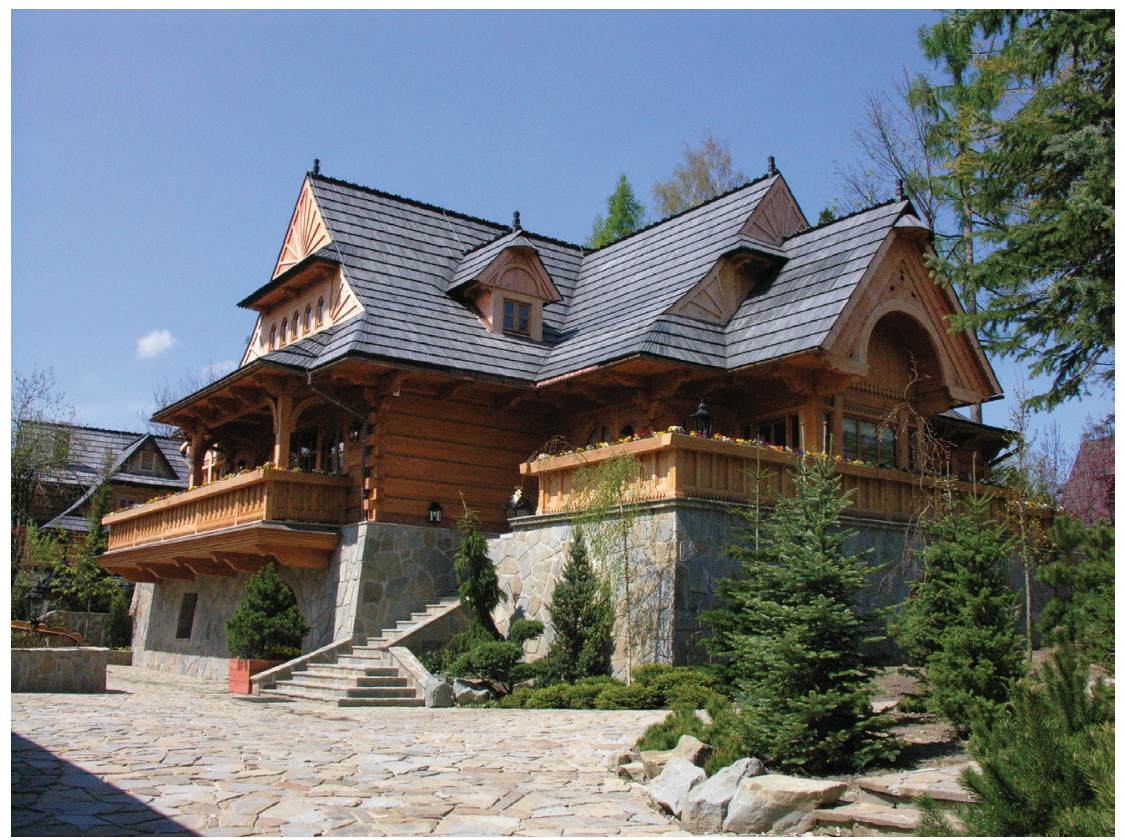

II. 36. Budynek rekreacyjny przy „Witkiewiczówce” na Antałówce (2013, proj. K. Kiełb, współpraca J. Kowalczyk). Fot. Dawid Moździerz, 2013. Zbiory prywatne

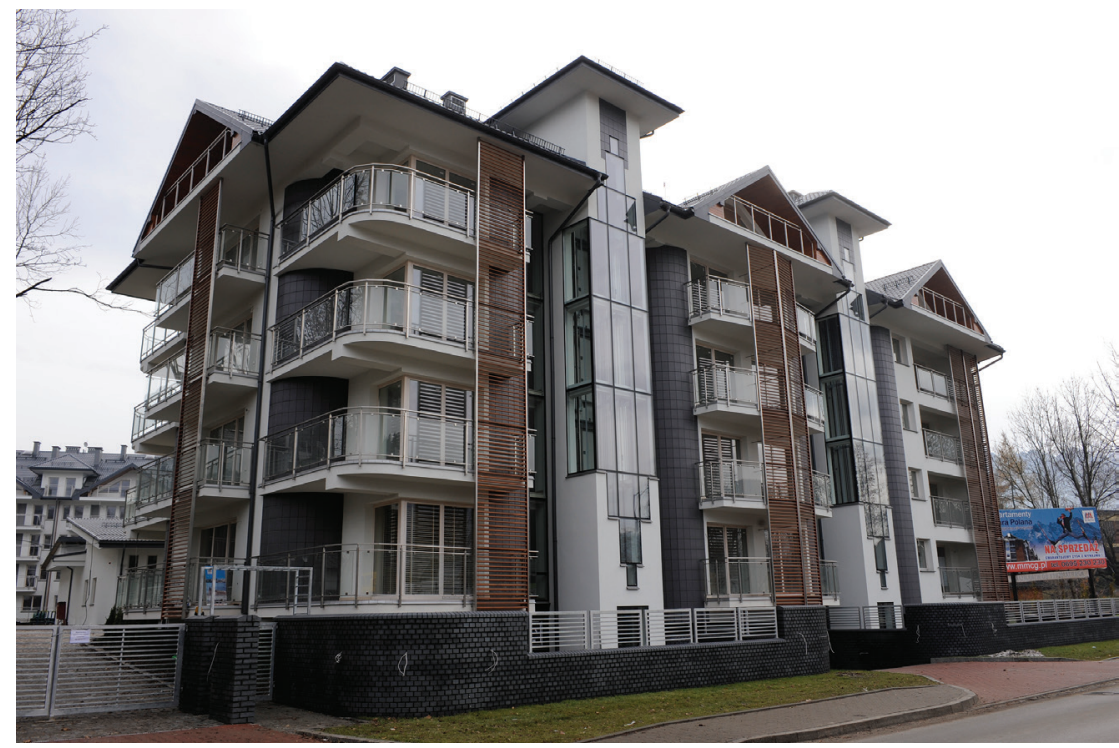

II. 37. Apartamentowce „Stara Polana” przy ul. Nowotarskiej (2007-2008, proj. S. Topór). Fot. Dawid Moździerz, 2009. Zbiory prywatne 


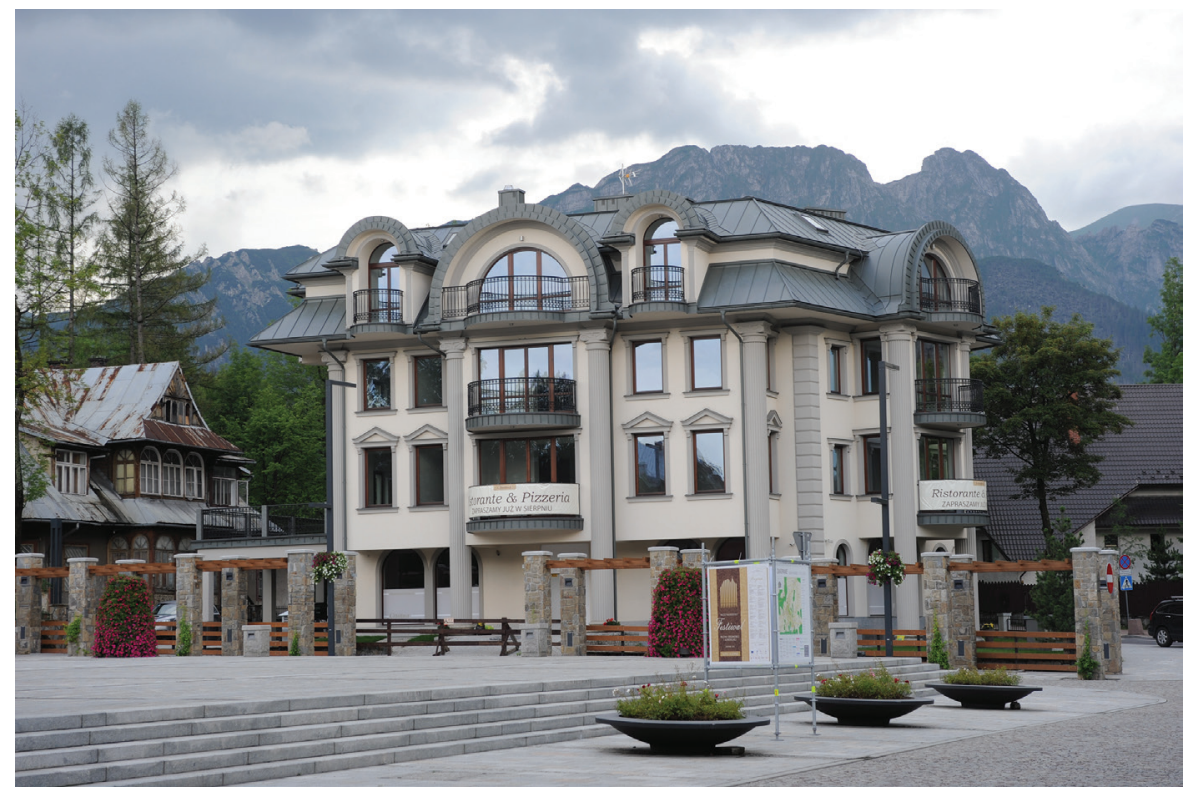

II. 38. Budynek mieszkalno-usługowy „Polonia” przy placu Niepodległości (2012-2014, proj. S. Topór). Fot. Dawid Moździerz, 2014. Zbiory prywatne

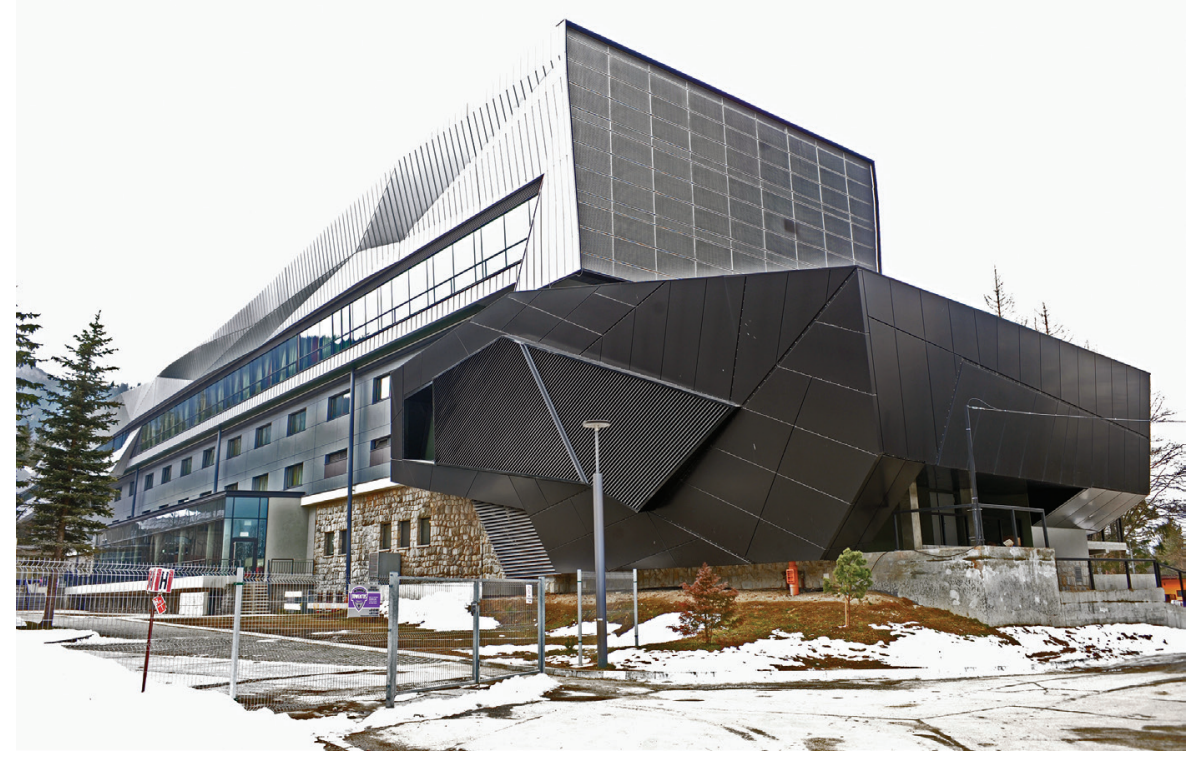

II. 39. Centralny Ośrodek Sportowy - Ośrodek Przygotowań Olimpijskich Zakopane (2010-2012, proj. S. Karpiel, T.T. Stopa, P. Walorek). Fot. Dawid Moździerz, 2013. Zbiory prywatne 


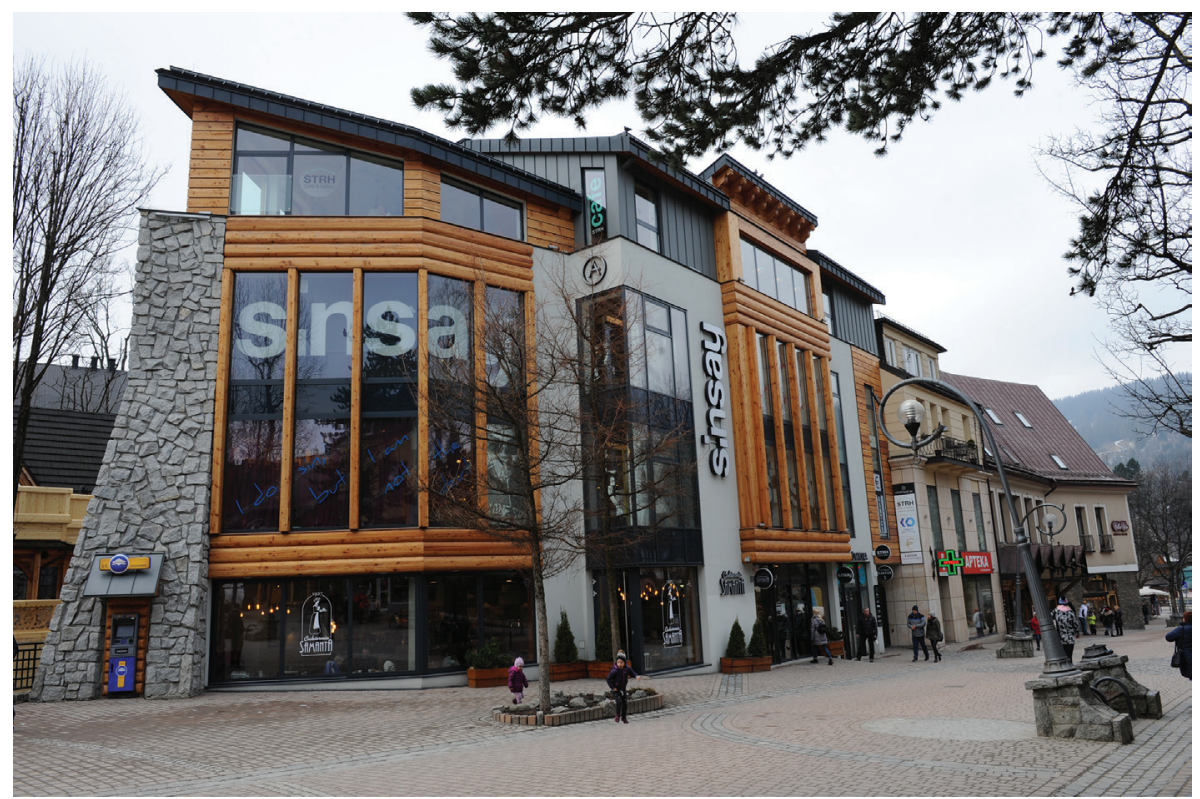

II. 40. Budynek usługowy z cukiernią „Samanta” przy ul. Krupówki (2015-2016, proj. Jacek Burdziński). Fot. Zbigniew Moździerz, 2017. Zbiory prywatne

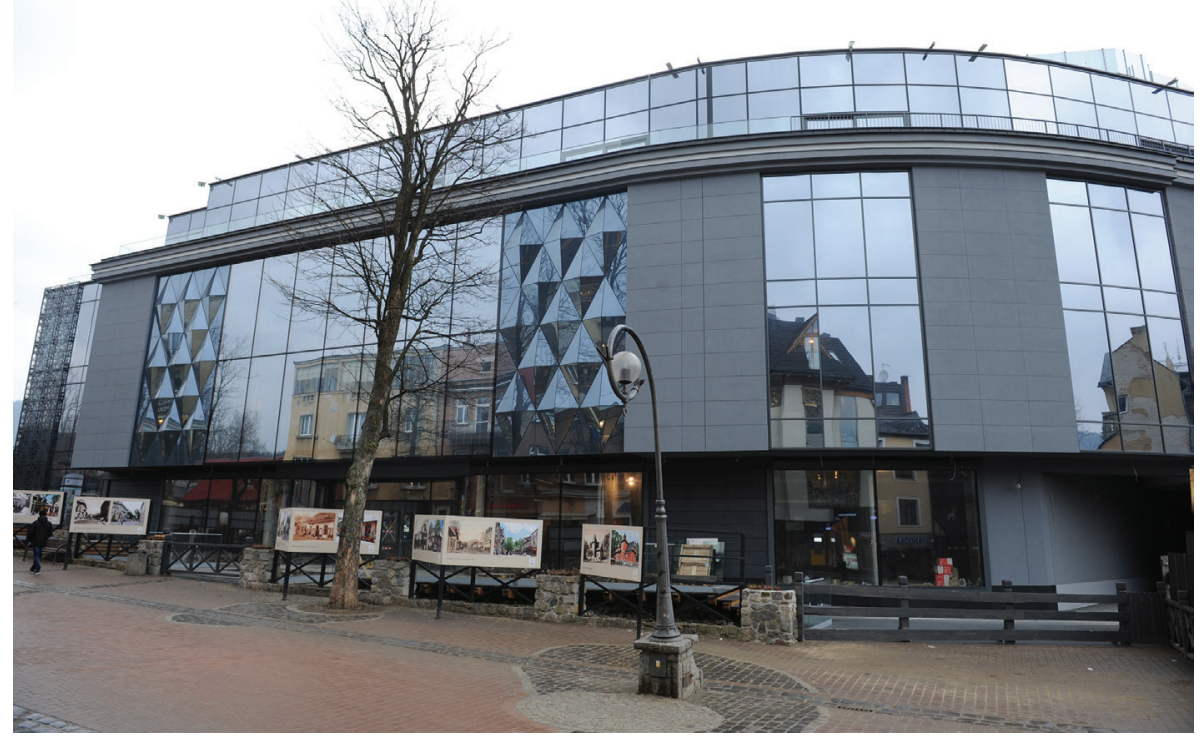

II. 41. Centrum Handlowe „Krupówki” przy ul. Krupówki (2012-2017, proj. A. i R. Rafaczowie). Fot. Zbigniew Moździerz, 2017. Zbiory prywatne 


\section{PRZYPISY}

1 J. Dajewski, Współczesne problemy architektury Zakopanego, „Architektura”, 4-5/1971, s. 157 i nast..; Z. Moździerz, Architektura budowli turystycznych w Tatrach Polskich i Zakopanem (1918-1975), „Wierchy”, 74/2008 [wyd. 2010], s. 65-104.; tenże, Główne nurty architektury Zakopanego (1600-2008), [w:] Architektura ziem górskich. Wczoraj-dziś jutro, red. M. Ponikiewska-Arct, Nowy Targ 2011, s. 39-58.

2 S. Żychoń, Rozwój przestrzenny i budownictwo, [w:] Zakopane. Czterysta lat dziejów, t. 1, Kraków 1991, s. 419-482.

3 Tamże; zob, też: Z. Moździerz, Architektura budowli turystycznych..., dz. cyt.; tenże, Urbanistyka i architektura, [w:] 75 lat praw miejskich Zakopanego, Zakopane 2008, s. 55-94; tenże, Główne nurty architektury Zakopanego..., dz. cyt.

4 J.S. Wroński, Architektura nowo zbudowanych kościołów w Zakopanem. Próba charakterystyki, [w:] 150 lat organizacji parafialnej w Zakopanem (1847-1997), pod red. M. Rokosza, Kraków 1998, s. 187-208; Z. Tołłoczko, Jeszcze o „stylu zakopiańskim” i jego wpływie na architekturę modernistycznq. Przyczynek do kwestii zaniku ludowej inspiracji w architekturze końca XX wieku, „Czasopismo Techniczne”, 1-A /2000, s. 16-25; Z. Moździerz, Urbanistyka i architektura..., dz. cyt.; tenże, Główne nurty architektury Zakopanego..., dz. cyt.

5 A.K. Olszewski, Poszukiwanie stylu narodowego w architekturze polskiej ostatniego stulecia, "Architektura", 3-4/1977, s. 55-66.

6 Z. Moździerz, Urbanistyka i architektura..., dz. cyt.; tenże, Główne nurty architektury Zakopanego..., dz. cyt.; tenże, Architektura i rozwój przestrzenny Zakopanego 1600-2013, Wydawnictwa TMT, Zakopane 2013.

7 Tamże.

8 Informacja jednego z inwestorów - Zbigniewa Bachledy.

9 L. Chwistek, Zagadnienia współczesnej architektury, „Nowa Sztuka”, 1/1921, s. 13.

10 Tamże, s. 13-14.

${ }^{11}$ Więcej na ten temat zob.: Z. Moździerz, Rozważania na temat architektury per formatywnej, [w:] Teatr. Teatralizacja. Performatywność, pod red. T. Pękali, Wydawnictwo UMCS, Lublin 2016, s. 297-322.

\section{BIBLIOGRAFIA}

Chrzanowski T., Kornecki M., Sztuka ziemi krakowskiej, Kraków 1982.

Chwistek L., Zagadnienia współczesnej architektury, „Nowa Sztuka”, 1/1921, s. 13.

Dajewski J., Współczesne problemy architektury Zakopanego, „Architektura”, 4-5/1971, s. 157 i nast.

Górska A., Schroniska tatrzańskie, „Architektura”, 4-5/1971, s. 150-156.

Górska A., Różyska K., Przegląd współczesnej architektury Podhala, „Architektura”, 2/1955, s. 34-43.

Kadłuczka A., Regionalizm jako forma ochrony narodowych wartości środowiska kulturowego, [w:] Aktualne problemy planistyczne i architektoniczne w zespołach architektury regional- 
nej i ich sq̨siedztwie. Materiały z III Ogólnopolskiego Sympozjum Architektury Regionalnej, pod red. Z. Radziewanowskiego, J. Zielińskiego, Kraków-Zakopane 1982, s. 39-45.

Kosiński W., Regionalizm i postmodernizm - rekonesans, [w:] Aktualne problemy planistyczne i architektoniczne w zespołach architektury regionalnej i ich sqsiedztwie. Materiały z III Ogólnopolskiego Sympozjum Architektury Regionalnej, pod red. Z. Radziewanowskiego i J. Zielińskiego. Kraków-Zakopane 1982, s. 87-105.

Moździerz Z., Architektura budowli turystycznych w Tatrach Polskich i Zakopanem (1918-1975), „Wierchy", 74/2008 [wyd. 2010], s. 65-104.

Moździerz Z., Architektura i rozwój przestrzenny Zakopanego 1600-2013, Wydawnictwa TMT, Zakopane 2013.

Moździerz Z., Od szałasu do apartamentowca, „Góry - Literatura - Kultura”, 9/2015, s. 93-117. Moździerz Z., Rozważania na temat architektury per formatywnej, [w:] Teatr. Teatralizacja. Performatywność, pod red. T. Pękali, Wydawnictwo UMCS, Lublin 2016, s. 297-322.

Olszewski A.K., Poszukiwanie stylu narodowego w architekturze polskiej ostatniego stulecia, „Architektura”, 3-4/1977, s. 55-66.

Pawlicki B.M., Percepcja wartości regionalnego budownictwa zabytkowego, [w:] Aktualne problemy planistyczne $i$ architektoniczne $w$ zespołach architektury regionalnej $i$ ich sqsiedztwie. Materiały z III Ogólnopolskiego Sympozjum Architektury Regionalnej, pod red. Z. Radziewanowskiego, J. Zielińskiego, Kraków-Zakopane 1982, s. 46-49.

Pinkwart M., Długołęcka-Pinkwart L., Zakopane. Przewodnik historyczny, Bielsko-Biała 2003. Radziewanowski Z., Kryterium logiki w architekturze regionalnej, [w:] Kierunki i metody współczesnego regionalizmu w architekturze, red. Z. Radziewanowski, J. Zieliński, Kraków-Zakopane 1984.

Radziewanowski Z., O niektórych problemach regionalizmu i ekologii w architekturze i urbanistyce, Kraków 2005.

Tołłoczko Z., Jeszcze o „stylu zakopiańskim” i jego wpływie na architekturę modernistycznq. Przyczynek do kwestii zaniku ludowej inspiracji w architekturze końca XX wieku, „Czasopismo Techniczne", 1-A /2000, s. 16-25.

Trojanowski J., Przyczyny degradacji zespołu przestrzennego centrum Zakopanego, [w:] Aktualne problemy planistyczne i architektoniczne w zespołach architektury regionalnej i ich sq̨iedztwie. Materiały z III Ogólnopolskiego Sympozjum Architektury Regionalnej, pod red. Z. Radziewanowskiego i J. Zielińskiego, Kraków-Zakopane 1982, s. 79-86.

Zieliński J., Wpływ stylu zakopiańskiego na rozwój regionalizmu w architekturze polskiejpróba retrospekcji, [w:] Aktualne problemy planistyczne i architektoniczne w zespołach architektury regionalnej i ich sqsiedztwie. Materiały z III Ogólnopolskiego Sympozjum Architektury Regionalnej, pod red. Z. Radziewanowskiego, J. Zielińskiego, KrakówZakopane 1982, s. 183-213.

Zin W., Rola architektury regionalnej w dobie budownictwa masowego, [w:] Aktualne problemy planistyczne i architektoniczne w zespołach architektury regionalnej i ich sqsiedztwie. Materiały z III Ogólnopolskiego Sympozjum Architektury Regionalnej, pod red. Z. Radziewanowskiego, J. Zielińskiego, Kraków-Zakopane 1982, s. 37-38.

Żychoń S., Rozwój przestrzenny i budownictwo, [w:] Zakopane. Czterysta lat dziejów, t. 1, Kraków 1991, s. 419-482. 